http://jmscr.igmpublication.org/home/ ISSN (e)-2347-176x ISSN (p) 2455-0450 crossref DOI: https://dx.doi.org/10.18535/jmscr/v9i3.22

\title{
Clinical Profile of Acute Viral Hepatitis in Children - In Southern Assam
}

Authors

\section{Dr Sumit Das ${ }^{1}$, Dr Anupama Deka², Dr Tanmay Biswas ${ }^{3}$}

${ }^{1}$ Associate professor, Department of Pediatrics, Silchar Medical College and Hospital, Silchar, Assam ${ }^{2}$ Professor and HOD, Department of Pediatrics Silchar Medical College and Hospital, Silchar, Assam ${ }^{3}$ PGT, Department of Pediatrics, Silchar Medical College and Hospital, Silchar, Assam

\begin{abstract}
Background: Viral hepatitis defined as infection of the liver caused by hepatotropic and/or nonhepatotropic viruses. Acute hepatitis is a self-limiting illness characterized by an abrupt onset of symptoms with the hepatocellular inflammation usually resolving completely within 4-6 weeks. The clinical spectrum of acute viral hepatitis ranges from entirely subclinical and in apparent infection to rapidly progressing and fulminant hepatic failure. India is hyper-endemic for hepatitis $A$ and $E$ virus infection. Purpose of this study was to identify the etiology, and to assess the clinical and biochemical profile, complications and final outcome of acute viral hepatitis in children.

Method: This was a prospective observational study, conducted in department of Pediatrics, Silchar Medical College and Hospital, among the children from 6month to 12years of age over a period of 1 year (July 2019 to June 2020). A total of 56 children with clinical diagnosis of acute viral hepatitis were included in the study. Data on clinical profile, laboratory parameters were obtained and analysis was performed.
\end{abstract}

Results: Among 56 cases 32(57.14\%) were boys and 24 were girls (42.85\%). Mean age group was $7.37 \pm$ 2.49 years. Virology marker revealed 41 (73.21\%) cases positive for hepatitis A(HAV), 6(10.71\%) cases positive for hepatitis $E(H E V)$, and co-infection with HAV and HEV in 1(1.78\%) case, no specific etiology was detected in $8(14.28 \%)$ cases, no positive hepatitis B and hepatitis C cases were detected. Jaundice was the most common (100\%) presenting complaint, followed by fever (96.42\%), high colored urine (83.92\%), pain abdomen (80.35\%). Conjugated hyperbilirubinemia was detected in all (100\%) the HAV, HEV positive cases, hepatic enzymes raised above 5 times of normal limit in all the HAV, HEV positive cases. Significant elevations in hepatic enzymes were seen more commonly in children with HEV infection. INR more than 2.5 was noticed among $4 \mathrm{HAV}$ positive cases $(9.75 \%)$ and $1 \mathrm{HEV}$ positive case (16.67\%). Acute liver failure was seen in 3 children, and among them 2(66.67\%) children were infected with HAV and 1(33.33\%) child was infected with HEV. All the 3 cases of acute liver failure died after 4-5 days of admission.

Conclusion: Hepatitis A is most common cause of acute viral hepatitis in pediatrics population. Hepatitis E infection leads a more severe clinical course than HAV infection.

Keywords: Acute viral hepatitis, hyperbilirubinemia, Hepatitis A, Hepatitis E. 


\section{Introduction}

Viral hepatitis defined as infection of the liver caused by hepatotropic and/or non-hepatotropic viruses.

The condition can be self-limiting or can progress to fibrosis (scarring). ${ }^{1}$ Acute hepatitis is a selflimiting illness characterized by an abrupt onset of symptoms with the hepatocellular inflammation usually resolving completely within 4-6 weeks. When there is a continuing inflammation beyond six months (three months in children), it is labeled as chronic hepatitis. ${ }^{2}$

Viral hepatitis continues to be a major health problem in both developing and developed countries. This disorder is caused by at least 5 pathogenic hepatotropic viruses recognized to date: hepatitides A (HAV), B(HVB), C (HCV), D (HDV), and E (HEV) viruses. Many other nonhepatotropic viruses (and diseases) can cause hepatitis, usually as 1 component of a multisystem disease. These include herpes simplex virus, cytomegalovirus, Epstein-Barr virus, varicellazoster virus, HIV, rubella, adenovirus, enteroviruses, parvovirus B19, and adenovirus. ${ }^{3}$

The clinical spectrum of acute viral hepatitis ranges from entirely subclinical and inapparent infection to rapidly progressing and fulminant hepatic failure. Hepatitis A (HAV) and E (HEV) viruses are feco-orally transmitted and selflimiting, whereas hepatitis B (HBV), C (HCV) and D (HDV) are transmitted parenterally and may progress to chronic hepatitis. India is hyperendemic for hepatitis A andE. ${ }^{4}$

Acute hepatitis resulting from most etiology has similar clinical features. The characteristic clinical features of acute hepatitis include nausea, vomiting, right hypochondrial pain, and jaundice. The prodromal phase of nonspecific symptoms, including fever, myalgia and anorexia is characteristic of viral hepatitis, but may also be seen in other conditions.

The syndrome of acute hepatitis is usually diagnosed in the presence of elevated serum transaminase. The cut-off for diagnosis is usually variable, ranging from an elevation of five to ten times of the upper limit of normal. Alkaline phosphatase (ALP) elevation is seen in all cases of acute hepatitis but is usually less than three times of upper limit of normal. The ALP elevation is proportionately less for the degree of jaundice if present. ${ }^{5,8}$ Viral hepatitis is a common disease in India and it occurs in epidemic and endemic forms. ${ }^{6}$ My present study described clinical profile of acute viral hepatitis from a tertiary care center in southern part of Assam.

\section{Aims of the Study}

Aims of this study to evaluate and understanding of the clinical profile of acute viral hepatitis.

\section{Objectives of the Study}

To identify the etiology, and to assess the clinical and biochemical profile, complications and final outcome of acute viral hepatitis in children.

\section{Materials and Methods}

A. Source of data: Patients attended in the Pediatrics Department at Silchar Medical College and Hospital during the study period as per the inclusion criteria were included.

B. Place of study: Department of Pediatrics, Silchar Medical College and Hospital, Silchar, Assam, India.

C. Duration of study: The duration of study was one year, July 2019 to June 2020.

D. Age group: More than 6 months to 12 years of age

\section{F. Inclusion Criteria}

1) Children with more than 6 month of age but less than 12 years of age presented with acute onset of jaundice, fever, vomiting/nausea, abdominal pain, anorexia, malaise, high color urine were included.

2) Those cases with acute onset of symptoms and positive for viral markers like anti Hepatitis A or E IgM, or $\mathrm{HbS} \mathrm{Ag} \mathrm{for} \mathrm{HBV}$, Anti $\mathrm{HCV}$ were included.

G. Exclusion Criteria: Patients with chronic liver disease, biliary obstruction, hemolytic diseases, active tuberculosis and on anti-tubercular drug, 
inherited metabolic disorder, autoimmune hepatitis, recent history of hepatotoxic drug or toxin exposure, diagnosed malaria or enteric fever were excluded by history taking, clinical examination, and biochemical examination.

\section{H. Methodology:}

This was a prospective observational study, conducted in department of Pediatrics, Silchar Medical College, Silchar.

Children presented with acute symptoms of jaundice, fever, pain abdomen, nausea/vomiting, anorexia, malaise, high color urine, in the department of Pediatrics SMCH were included in the study group as per inclusion criteria and was excluded from the study group as per exclusion criteria, total 56 study subjects were included in our study. After taking informed verbal consent from the parent/guardian a detail history, clinical examination was done at the time of admission, the clinical assessment includeslevel of consciousness, facies, icterus, pallor, organomegaly, hepatic tenderness, any signs of biliary obstruction, any signs of chronic diseaseswere detected. Those with CNS symptoms like seizures, decrease level of consciousness was shifted to PICU, other cases were admitted to general pediatric ward.

In each case detail history regarding socioeconomic status, water supply, family contacts, personal hygiene blood transfusion, drug history, food habits, herbal medicine intake, residence in urban/rural also obtained.

After history and clinical examination these children were subjected to laboratory investigation for complete blood count, including reticulocyte count, and RDW, liver function test, PT/APTT, INR, viral markers like anti HAV and HEV IgM, hepatitis B surface antigen, and Anti HCV total antibodies, other than this for exclusion plasmodium vivax, plasmodium falciparum antigen, andperipheral blood smear, WIDAL test, and USG abdomen was done on admission. Laboratory investigation was repeated according to the clinical condition of patient. In selective cases serum electrolyte, ABG, blood sugar, KFT, and serum ammonia was done. Each patient was observed till recovery or death.

\section{Results and Observations}

Figure 1: Distribution of study subjects according to age and sex $(n=56)$.

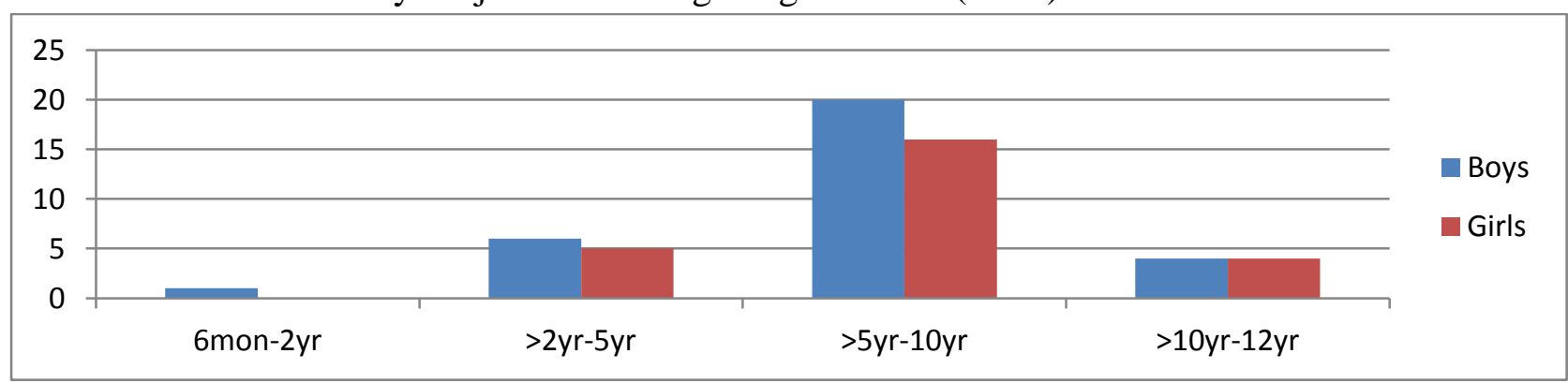

Table 1: Distribution of study subjects according to modified Kuppuswamýs Socioeconomic scale

\begin{tabular}{|l|c|c|}
\hline Socioeconomic class & Total number of patients(n=56) & Percentage $(\%)$ \\
\hline Upper & 2 & $3.57 \%$ \\
\hline Upper middle & 5 & $8.92 \%$ \\
\hline Lower middle & 14 & $25 \%$ \\
\hline Upper lower & 23 & $41.07 \%$ \\
\hline Lower & 12 & $21.42 \%$ \\
\hline
\end{tabular}


Table 2: Distribution of study subjects according to clinical symptoms

\begin{tabular}{|l|c|c|}
\hline Symptoms & Number of patients(n=56) & Percentage (\%) \\
\hline Fever & 54 & $96.42 \%$ \\
\hline Jaundice & 56 & $100 \%$ \\
\hline Anorexia & 43 & $76.78 \%$ \\
\hline Nausea & 37 & $66.07 \%$ \\
\hline Vomiting & 29 & $51.78 \%$ \\
\hline High colored urine & 47 & $83.92 \%$ \\
\hline Pruritus & 7 & $12.50 \%$ \\
\hline Pain abdomen & 45 & $80.35 \%$ \\
\hline Diarrhea & 3 & $5.35 \%$ \\
\hline Abnormal behavior & 3 & $5.35 \%$ \\
\hline
\end{tabular}

Table 3: Distribution of study subjects according to clinical signs

\begin{tabular}{|l|c|c|}
\hline Physical finding & Number of patients(n=56) & Percentage (\%) \\
\hline Icterus & 56 & $100 \%$ \\
\hline Pallor & 9 & $16.07 \%$ \\
\hline Hepatomegaly & 49 & $87.50 \%$ \\
\hline Splenomegaly & 4 & $7.14 \%$ \\
\hline Hepatic tenderness & 43 & $76.78 \%$ \\
\hline Ascites & 3 & $5.35 \%$ \\
\hline Edema & 2 & $3.57 \%$ \\
\hline
\end{tabular}

Table 4: Distributions of study subjects according to causative agents

\begin{tabular}{|l|c|c|}
\hline Name of the viruses & Total number reactive cases(n=56) & Percentage \\
\hline HAV & 41 & $73.21 \%$ \\
\hline HEV & 6 & $10.71 \%$ \\
\hline HBV & 0 & - \\
\hline HCV & 0 & - \\
\hline Coinfection with HAV and HEV & 1 & $1.78 \%$ \\
\hline Non A to E & 8 & $14.28 \%$ \\
\hline
\end{tabular}

Figure 2: Age wise distribution of study subjects depending on viral positivity

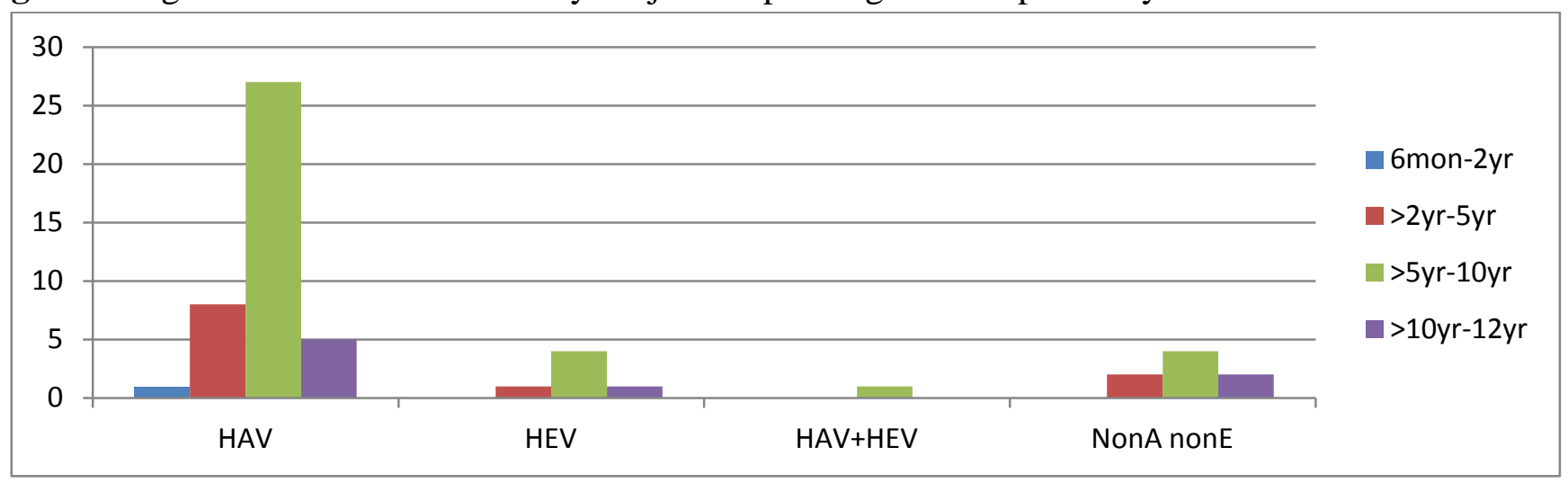

Figure 3: Sex wise distribution of study subjects depending on viral positivity.

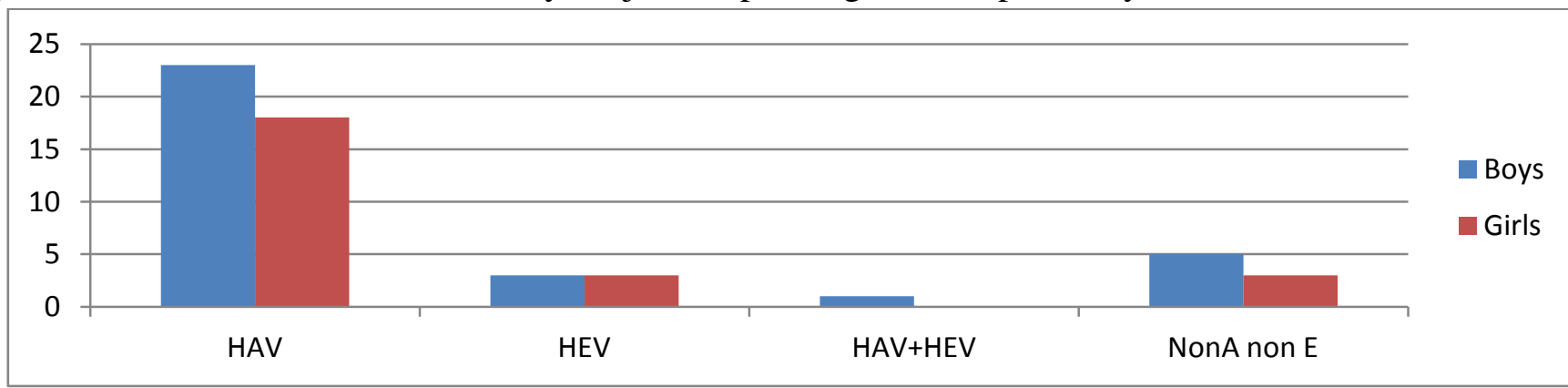


Table 5: Hematological profile among study subjects at the time of presentation

\begin{tabular}{|c|c|c|c|c|}
\hline Parameters & $\begin{array}{c}\text { HAV } \\
\text { (no of patient and } \\
\%)(\mathrm{n}=41 \text { ) }\end{array}$ & $\begin{array}{r}\text { HEV } \\
\text { (no of patient and } \\
\%)(\mathrm{n}=6)\end{array}$ & $\begin{array}{c}\text { HAV+HEV coinfection } \\
\text { (no of patient and } \%) \\
(\mathrm{n}=1)\end{array}$ & $\begin{array}{l}\text { Non A to E(no of } \\
\text { patient and \%) } \\
(\mathrm{n}=8)\end{array}$ \\
\hline \multicolumn{5}{|l|}{ Hemoglobin } \\
\hline$>11.5 \mathrm{gm} \%$ & $35(85.36 \%)$ & $5(83.33 \%)$ & 0 & $6(75 \%)$ \\
\hline$<11.5 \mathrm{gm} \%$ & $6(14.63 \%)$ & $1(16.67 \%)$ & $1(100 \%)$ & $2(25 \%)$ \\
\hline \multicolumn{5}{|l|}{ WBC count } \\
\hline$<4000 / \mu \mathrm{l}$ & 0 & 0 & 0 & 0 \\
\hline $\begin{array}{c}4000-11000 / \\
\mu 1\end{array}$ & $34(82.92 \%)$ & $4(66.67 \%)$ & $1(100 \%)$ & $8(100 \%)$ \\
\hline$>11000 / \mu \mathrm{l}$ & $7(17.07 \%)$ & $2(33.34 \%)$ & 0 & 0 \\
\hline \multicolumn{5}{|l|}{ Platelet count } \\
\hline$>1.5 \mathrm{lakh} / \mu \mathrm{l}$ & $39(95.12 \%)$ & $6(100 \%)$ & $1(100 \%)$ & $8(100 \%)$ \\
\hline$<1.51 \mathrm{akh} / \mathrm{ul}$ & $2(4.87 \%)$ & 0 & 0 & 0 \\
\hline
\end{tabular}

Table 6: Distribution of serum bilirubin level among study subjects at the time of presentation

\begin{tabular}{|c|c|c|c|c|}
\hline Parameters & $\begin{array}{c}\text { HAV } \\
(\text { no of patient and } \\
\%)(\mathrm{n}=41)\end{array}$ & $\begin{array}{r}\text { HEV } \\
(\text { no of patient and } \\
\%)(\mathrm{n}=6)\end{array}$ & $\begin{array}{c}\text { HAV+HEV coinfection } \\
(\text { no of patient and }) \\
(\mathrm{n}=1)\end{array}$ & $\begin{array}{c}\text { Non A to E (no } \\
\text { of patient and \%) } \\
(\mathrm{n}=8)\end{array}$ \\
\hline \multicolumn{5}{|c|}{ Total serum bilirubin } \\
\hline$>1.2 \mathrm{mg} / \mathrm{dl}$ & 0 & 0 & 0 & 0 \\
\hline$>5-1.2 \mathrm{mg} / \mathrm{dl}$ & $7(17.07 \%)$ & $1(16.67 \%)$ & 0 & $6(75 \%)$ \\
\hline$>10 \mathrm{mg} / \mathrm{dl}$ & $15(36.58 \%)$ & $2(33.33 \%)$ & $1(100 \%)$ & $2(25 \%)$ \\
\hline $\begin{array}{c}\text { Conjugated } \\
\text { hyperbilirubinemia }\end{array}$ & $19(46.34 \%)$ & $3(50 \%)$ & $1(100 \%)$ & 0 \\
\hline
\end{tabular}

Table 7: Distribution of hepatic enzymes level among study subjects at the time of presentation.

\begin{tabular}{|c|c|c|c|c|}
\hline Parameters & $\begin{array}{c}\text { HAV } \\
\text { (no of patient and } \\
\%)(\mathrm{n}=41)\end{array}$ & $\begin{array}{l}\text { HEV } \\
\text { (no of patient and \%) } \\
(\mathrm{n}=6)\end{array}$ & $\begin{array}{c}\text { HAV+HEV coinfection } \\
\text { (no of patient and } \%) \\
(\mathrm{n}=1)\end{array}$ & $\begin{array}{l}\text { Non A to E (no of } \\
\text { patient and } \\
\%)(\mathrm{n}=8)\end{array}$ \\
\hline \multicolumn{5}{|l|}{ ALT/SGPT } \\
\hline $5-40 \mathrm{U} / \mathrm{L}$ & 0 & 0 & 0 & $1(12.5 \%)$ \\
\hline$>40-500 \mathrm{U} / \mathrm{L}$ & $12(29.26 \%)$ & 0 & 0 & $\begin{array}{c}5 \\
(62.5 \%)\end{array}$ \\
\hline$>500-1000 \mathrm{U} / \mathrm{L}$ & $21(51.21 \%)$ & $2(33.34 \%)$ & $1(100 \%)$ & $2(25 \%)$ \\
\hline$>1000 \mathrm{U} / \mathrm{L}$ & $8(19.51 \%)$ & $4(66.67 \%)$ & 0 & 0 \\
\hline \multicolumn{5}{|l|}{ AST/SGOT } \\
\hline $5-40 \mathrm{U} / \mathrm{L}$ & 0 & 0 & 0 & $\begin{array}{c}1 \\
(12.5 \%)\end{array}$ \\
\hline$>40-500 \mathrm{U} / \mathrm{L}$ & $17(41.46 \%)$ & $1(16.67 \%)$ & 0 & $6(75 \%)$ \\
\hline$>500-1000 \mathrm{u} / \mathrm{L}$ & $19(46.34 \%)$ & $3(50 \%)$ & $1(100 \%)$ & $1(12.5 \%)$ \\
\hline$>1000 \mathrm{U} / \mathrm{L}$ & $5(12.19 \%)$ & $2(33.34 \%)$ & 0 & 0 \\
\hline \multicolumn{5}{|c|}{ Alkaline phosphatase } \\
\hline$<345 \mathrm{U} / \mathrm{L}$ & $28(68.29 \%)$ & $4(66.67 \%)$ & $1(100 \%)$ & $6(75 \%)$ \\
\hline$>345 \mathrm{U} / \mathrm{L}$ & $13(31.71 \%)$ & $2(33.34 \%)$ & 0 & $2(25 \%)$ \\
\hline
\end{tabular}


Table 8: Distribution of serum albumin level and INR among study subjects at the time of presentation.

\begin{tabular}{|c|c|c|c|c|}
\hline Parameters & $\begin{array}{c}\text { HAV } \\
\text { (no of patient and } \\
\%)(\mathrm{n}=41) \\
\end{array}$ & $\begin{array}{r}\mathrm{HEV} \\
\text { (no of patient and } \\
\%)(\mathrm{n}=6\end{array}$ & $\begin{array}{c}\text { HAV+HEV coinfection } \\
\text { (no of patient and } \% \text { ) } \\
(\mathrm{n}=1)\end{array}$ & $\begin{array}{c}\text { Non A to E (no of } \\
\text { patient and \%) } \\
(\mathrm{n}=8)\end{array}$ \\
\hline \multicolumn{5}{|c|}{ Serum albumin } \\
\hline$>3.5 \mathrm{gm} / \mathrm{dl}$ & $37(90.24 \%)$ & $5(83.33 \%)$ & $1(100 \%)$ & $8(100 \%)$ \\
\hline$<3.5 \mathrm{gm} / \mathrm{dl}$ & $4(9.75 \%)$ & $1(16.67 \%)$ & 0 & 0 \\
\hline \multicolumn{5}{|l|}{ INR } \\
\hline$<1.5$ & $29(85.36 \%)$ & $4(66.67 \%)$ & $1(100 \%)$ & $7(87.5 \%)$ \\
\hline $1.5-2.5$ & $8(19.51 \%)$ & $1(16.67 \%)$ & 0 & $1(12.5 \%)$ \\
\hline$>2.5$ & $4(9.75 \%)$ & $1(16.67 \%)$ & 0 & 0 \\
\hline
\end{tabular}

Total number of cases in our study were 56 among which $32(57.14 \%)$ were boys and 24 were girls $(42.85 \%)$, boys were predominant in this study. As shown in Fig.1; 11(19.64\%) cases were between $>2$ years to 5 years of age, 36(64.28\%) cases were between $>5$ years to 10 years of age, $8(14.28 \%)$ cases were between $>10 y r s$ to 12 and only one case was infant. Most of the children in our study belong to lower socioeconomic status with poor sanitation and history drinking of unsafe water. Children presented with variety of symptoms (Table 2) among which jaundice was the most common presenting complaint, it was present in all cases (100\%), followed byfever (96.42\%), high colored urine $(83.92 \%)$, pain abdomen $(80.35 \%)$, anorexia $(76.78 \%)$, nausea $(66.07 \%)$, vomiting $(51.78 \%), 3(5.35 \%)$ case presented with abnormal behavior and altered sensorium. Physical examination revealed variety of positive clinical features (Table 3) among which icterus was present in all case (100\%), followed by hepatomegaly $(87.50 \%)$, hepatic tenderness (76.78\%), pallor (16.07\%), splenomegaly $(7.14 \%)$, ascites $(5.35 \%)$, edema $(3.57 \%)$ cases.

Virology marker revealed (Table 4) that 41 (73.21\%) cases were positive for anti HAV IgM, followed by6(10.71\%) casespositive for anti HEV IgM, coinfection with HAV and HEV was found in $1(1.78 \%)$ case, hepatitis due to unknown cause $8(14.28 \%)$ cases, no positive HBV and HCV cases were detected.

Hemoglobin level <11.5gm\%(Table 5) was seen among $6(14.63 \%)$ HAV positive cases, among $1(16.67 \%)$ HEV positive case. Total serum bilirubin level was raised among all the cases (Table 6), total bilirubin raised more than 10 $\mathrm{mg} / \mathrm{dl}$ in, 19(46.34\%) and3(50\%) cases in HAV and HEV positive cases respectively. Conjugated hyperbilirubinemia was detected in all the HAV, HEV positive cases. Liver enzymes (ALT/SGPT, AST/SGOT)raised (Table 7) in all the HAV, HEV positive cases, ALT/SGPT raised more than 1000U/L in 5(12.9\%) and 2(33.34\%) in HAV and HEV positive cases respectively. Alkaline phosphatase raised more than 345U/L in $13(31.71 \%), 2(33.34 \%)$ and $2(25 \%)$ of HAV, HEV positive cases and hepatitis due to unknown causes respectively.

Serum albumin (Table 8) was normal in majority of the cases, was less than $3.5 \mathrm{gm} / \mathrm{dl}$ was detected in $4(9.75 \%), 1(16.67 \%)$ cases of HAV and HEV positive cases respectively. INR also within normal range in majority of cases, INR in the range of 1.5-2.5 among HAV, HEV positive and hepatitis due to unknown causes number of cases were $8(19.51 \%), 1(16.67 \%), 1(12.5 \%)$ respectively. INR more than 2.5 wasdetected $4(9.75 \%)$ cases of HAV positive and in $1(16.67 \%) \mathrm{HEV}$ positive case, among which three cases developed hepatic encephalopathy and died after 4-5days of admission.

\section{Discussion}

Acute viral hepatitis is an important health problem in children in the southern part of Assam, especially in the rural and slum areas and people belong to lower socioeconomic status where supply of safe drinking water is not available along with poor sanitation and poor personal 
hygiene. Our total study subjects were 56among which 31 were male and 25 were female, male: female ratio was $1.24: 1$, so in our study male subjects were predominant,this is comparable with study done by Behera MR et al. ${ }^{4}$ in eastern part of India (M: F ratio 2.2:1) in which there also stated that, boys are predominantly affected.

In our study majority of cases (64.28\%) were aged between 5-10 years of age, this is comparable with the study done by Behera MR et al. ${ }^{4}$ in eastern India reported higher prevalence in age group 5 to 10 years. Another study done by Kamath et al. ${ }^{7}$ also reported maximum number of cases $(61.6 \%)$ in 5-10-year age group.

In our study, HAV (73.21\%) was detected to be the most common cause of acute hepatitis followed by $\mathrm{HEV}$ (10.71\%); this is comparable with study done by Poddar $\mathrm{U}$ et al. $^{8}$ from Chandigarh India they have found that HAV infection is the most common cause $(64.5 \%)$ acute viral hepatitis in children followed by $\mathrm{HEV}$ infection(16.3\%)(8), also comparable with study done by Behera MR et al. ${ }^{4}$ they also found HAV $(63.15 \%)$ infection is most common most common cause acute viral hepatitis in children followed by $\mathrm{HBV}(10.52 \%)$, followed by $\mathrm{HEV}$ $(5.26 \%)$.

In our study we didn't find any positive HBV case. The incidence of acute hepatitis B is largely reduced during the last 20 years as a result of the use of vaccination and routine blood donor screening globally. ${ }^{9,10}$ However, acute HBV may still occur in adults and may results in fatal complications. ${ }^{11}$

Various presenting clinical symptoms and signs of viral hepatitis were noted in this study,icterus (100\%) was the most common presenting symptoms followed by fever(96.42\%), high colored urine(83.92\%), pain abdomen $(80.35 \%)$; this is comparable with study done by Parekh Z et al. $^{12}$ reported almost similar presenting complaints most common being jaundice (94\%) followed by fever (82\%). Clinical examination revealed icterus $(100 \%)$ was the most consistent signs followed by hepatomegaly $(87.50 \%)$, and hepatic tenderness $(76.78 \%)$ respectively; this is comparable with study done byGirish $\mathrm{N}$ et al. ${ }^{1}$ they also found that icterus (100\%) and hepatomegaly $(76 \%)$ were the most frequent presenting signs. Some atypical clinical presentation also noted among our study subjects in small percentage like splenomegaly $(7.14 \%)$, ascites $(5.35 \%)$, edema $(3.57 \%)$. Three children presented with abnormal behavior.

Biochemical study provides information regarding the extent of hepatic damage. Total serum bilirubin and hepatic enzymes were elevated almost all the cases in our study. Conjugated hyperbilirubinemia were noticed in most of the cases. We have found that cases with elevated liver enzymes (SGPT >1000U/L), bilirubinmore than $10 \mathrm{mg} / \mathrm{dl}$, INR of more than 1.5 had suffered more severe clinical course and took longer duration to recover. In comparison with HAV and $\mathrm{HEV}$, cases infected with HEV had suffered more severe clinical course than those infected with HAV.In our study among 56 cases 3 cases developed hepatic encephalopathy, 2 cases were infected with HAV and 1 case was infected with HEV and died after4-5 days of PICU admission.

\section{Conclusion}

HAV and HEV infections are the commonest cause of acute viral hepatitis in children in southern part of Assam. It is necessary to educate the general public in this region regarding preventive measures including use of safe drinking water, proper hand hygiene, proper waste disposal and use of sanitary latrine and initiative from government side regarding HAV vaccination.Health education regarding the clinical symptoms of acute viral hepatitis also important for general public for early identification and seeking of medical attention early so as to prevent morbidity and mortality related to the disease. 


\section{Bibliography}

1. Girish N., Sunil B., Ranganatha A. Devaranavadagi A clinical study of viral hepatitis in children: a prospective hospital-based study. International Journal of Contemporary Pediatrics. 2018 Mar;5(2): 563-568

2. Sathiyasekaran M. Viral Hepatitis. In; A Parthasarathy (eds) IAP TEXTBOOK OF PEDIATRICS. Sixth edition. New Delhi; Jaypee Brothers Medical Publishers (P) Ltd. 2016. p631-634.

3. Jensen M.K., Balistreri W. F. Viral Hepatitis. In; Kliegman R M,Stanton B F ,St Geme J W,Schor N F,Behrman R E(eds) Nelson Text Book of Pediatrics. First South Asia Edition. Amsterdam: Elsevier; 2016.p1942-1953.

4. Behera MR, Patnaik L. Clinicobiochemical profile and etiology of acute viral hepatitis in hospitalized children: A study from Eastern India. Indian J Child Health. 2016; 3(4):317-320.

5. Jagadisan B. Acute Hepatitis. In; Gupta P, Ramji S, Lodha R (eds) PG Textbook of Pediatrics. $2^{\text {nd }}$ Edition.New Delhi; The Health Sciences Publisher; 2018.p17621765.

6. Jabbar A, Pathan M. Clinical Profile of Viral Hepatitis at a Tertiary Care Centre in Rural Maharashtar: An Observational Study. IOSR Journal of Dental and Medical Sciences. 2015 oct. PP 26-28.

7. Kamath SR, Sathiyasekaran M, Raja TE, Sudha L. Profile of viral hepatitis A in Chennai. Indian Pediatr. 2009;46(7):642-3.

8. Poddar U, Thapa BR, Prasad A, Singh K. Changing Spectrum of Sporadic Acute Viral Hepatitis in Indian Children. Journal of Tropical Pediatrics. 2002 August: Vol. 48.
9. Zanetti AR, Romano L, Zappa A, Velati C (2006) Changingn patterns of hepatitis B infection in Italy and NAT testing for improving the safety of blood supply. J Clin Virol 36(1): S51-S55

10. Centre for disease control and prevention (2004) Acute hepatitis B among children and adolescents, United States 53(43): 1015-18.

11. Lisotti A, Azzaroli F, Buonfiglioli F, Montagnani M, Alessandrelli $\mathrm{F}$, et al. (2008) Lamivudine treatment for severe acute HBV hepatitis. Int J Med Sci 5(6): 309-12.

12. Parekh Z, Modi R, Banker D. Clinical study of hepatitis in children with special reference to viral markers. NHL J Med Sci. 2013;2(1):23-7. 